\title{
E Ring Chromosome with Persistent Left Superior Vena Cava and Hypertrophic Subaortic Stenosis*
}

\author{
STEWART WALD, $†$ ERIC ENGEL, WALTER E. NANCE, JACK DAVIES, \\ FRANCIS A. PUYAU, and BRUCE C. SINCLAIR-SMITH \\ From the Departments of Medicine, Pediatrics, and Anatomy, Vanderbilt University Medical School, \\ Nashville, Tennessee, U.S.A.
}

Hypertrophic subaortic stenosis and a persistent left superior vena cava draining into the left atrium have been observed individually in association with a variety of other cardiac defects (Shone et al., 1963; Molthan, Paul, and Lev, 1962; Lauer, DuShane, and Edwards, 1960; Gensini et al., 1959; Fraser et al., 1961). However, the occurrence of both defects in one patient has not previously been documented. The purpose of this report is to describe a patient who had both of these anomalies in association with $\mathrm{E}$ partial monosomy resulting from the presence of a ring chromosome.

\section{Case Report}

A 15-year-old white girl was born in 1953 when her mother was 26 years old and her father 31 years old. An older and two younger sibs were normal, but a fifth sib died at the age of 6 months of suffocation during a convulsion of unknown aetiology. A sixth pregnancy terminated in abortion during the third month. The patient was born uneventfully after a full-term pregnancy. Mental deficiency was suspected at birth, however, and was confirmed 17 months later when the patient was admitted to hospital for diagnostic studies which revealed no definite cause for the retardation. When the patient was 7, psychological evaluation showed moderate to severe retardation. At the age of 12 , the patient was admitted to a home for retarded children. At that time, her social age was 2.6 years, yielding a social quotient of 21. She was not toilet trained and had no speech.

On examination at age 12 , her height was $127.5 \mathrm{~cm}$., weight $24.5 \mathrm{~kg}$., head circumference $50 \mathrm{~cm}$., and blood pressure $100 / 60 \mathrm{~mm}$. $\mathrm{Hg}$. She was a severely retarded, poorly developed girl who sat or lay quietly, making occasional grasping movements with her hands. Her face was pointed anteriorly, and she had a protruding

Received September 23, 1968.

* This work was supported by USPHS Grants HE-08195, 5-M01-FR95, NB-06408-03, GM-11615-05 and Project 423 of the Children's Bureau.

† Present address: Department of Medicine, Emory University School of Medicine, Atlanta, Georgia, U.S.A. lower lip, moderate ptosis, a high-arched palate, andō mixed dentition, with malocclusion and crowding of the lower incisors (Fig. 1). The vessels of the fundi were slightly attenuated, and there was a choroidal colobomaN on the right. The frontal sinuses could not be transil- $\infty$ luminated. Her neck was webbed, and she had moderate pectus excavatum with wide-set nipples. Her hands were long and thin, and her skin was dry. There was bilateral genu recurvatum. The stance and gait were wide-based, but the deep tendon reflexes were sym- $\frac{\mathbb{D}}{3}$ metrical. Hearing and vision were grossly intact, ando the patient responded to noxious odours. The arterial

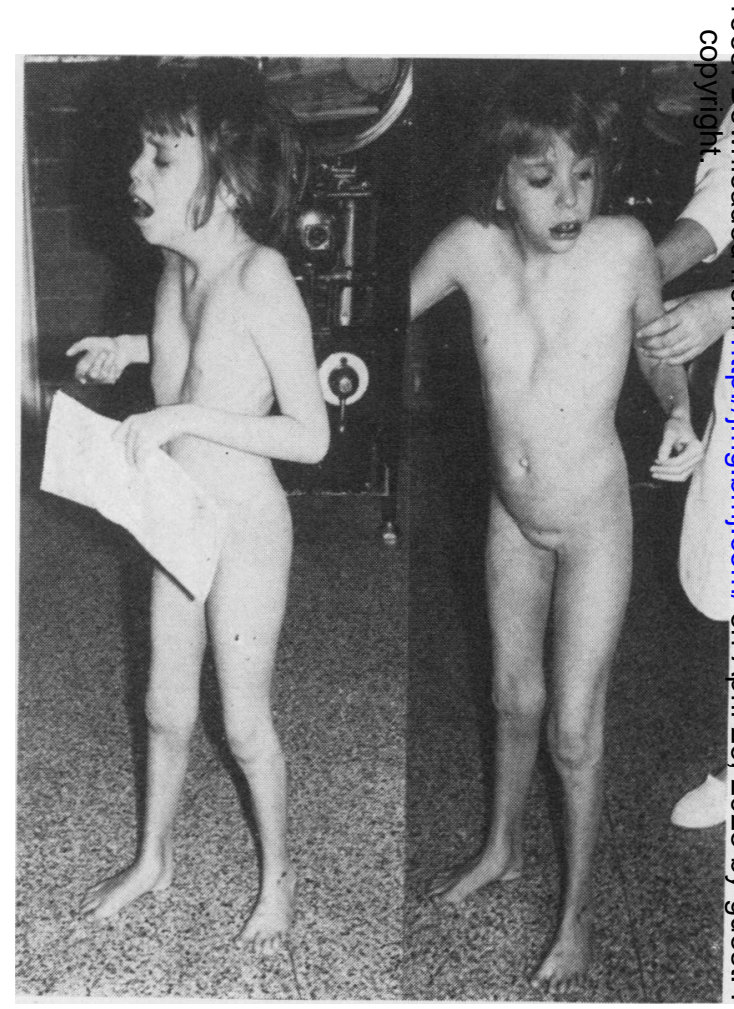

FIg. 1. Profile and front view of patient. 
TABLE I

BLOOD TYPING RESULTS

\begin{tabular}{|c|c|c|c|c|c|c|c|c|c|c|c|c|c|c|c|}
\hline \multirow{2}{*}{ Subject } & \multicolumn{15}{|c|}{ Blood Group System } \\
\hline & $\mathrm{ABO}$ & MNS & $\mathrm{Rh}$ & Jk & $\mathbf{P}$ & $\mathbf{L u}$ & Fy & $\mathbf{X g}$ & $\mathbf{B i}$ & G6PD & LDH & 6-PG & $\mathrm{Hb}$ & $\mathrm{Hp}$ & Tf \\
\hline $\begin{array}{l}\text { Father } \\
\text { Mother } \\
\text { Patient }\end{array}$ & $\begin{array}{l}\mathrm{O} \\
\mathrm{O} \\
\mathrm{O}\end{array}$ & $\begin{array}{l}\text { Ns } \\
\text { Ms } \\
\text { MNs }\end{array}$ & $\begin{array}{l}\text { ce.ce } \\
\text { CD.ce } \\
\text { ce.ce }\end{array}$ & $\begin{array}{l}\mathrm{aa} \\
\mathrm{bb} \\
\mathrm{ab}\end{array}$ & $\begin{array}{l}+ \\
+ \\
+\end{array}$ & $\begin{array}{l}a-b+ \\
a-b+ \\
a-b+\end{array}$ & $\begin{array}{l}a-b+ \\
a-b+ \\
a-b+\end{array}$ & $\begin{array}{l}a+ \\
a+ \\
a+\end{array}$ & $\begin{array}{l}a+ \\
a+ \\
a+\end{array}$ & $\begin{array}{l}\mathbf{B} \\
\mathbf{B} \\
\mathbf{B}\end{array}$ & $\begin{array}{l}\text { Norm } \\
\text { Norm } \\
\text { Norm }\end{array}$ & $\begin{array}{l}\text { Norm } \\
\text { Norm } \\
\text { Norm }\end{array}$ & $\begin{array}{l}\text { A } \\
\text { A } \\
\text { A }\end{array}$ & $\begin{array}{l}2-2 \\
2-2 \\
2-2\end{array}$ & $\begin{array}{l}\text { CC } \\
\text { CC } \\
\text { CC }\end{array}$ \\
\hline
\end{tabular}

TABLE II

DERMATOGLYPHIC ANALYSIS

\begin{tabular}{|c|c|c|c|c|c|c|c|c|c|c|c|c|c|c|c|}
\hline \multirow{2}{*}{\multicolumn{2}{|c|}{ Hand }} & \multicolumn{6}{|c|}{ Fingers } & \multicolumn{3}{|c|}{$\begin{array}{l}\text { Interdigital } \\
\text { Areas }\end{array}$} & \multirow{2}{*}{$\begin{array}{l}\text { Simian } \\
\text { Crease }\end{array}$} & \multirow{2}{*}{$\begin{array}{c}\text { Atd } \\
\text { Angle }\end{array}$} & \multirow{2}{*}{$\begin{array}{l}\text { Hypothenar } \\
\text { Area }\end{array}$} & \multirow{2}{*}{$\begin{array}{c}\text { Thenar } \\
\text { Area }\end{array}$} & \multirow{2}{*}{$\underset{\text { Triradius }}{\text { Axial }}$} \\
\hline & & $\mathrm{T}$ & 2 & 3 & 4 & 5 & Total & II I & III & IV & & & & & \\
\hline Left & $\begin{array}{l}\text { Pattern } \\
\text { Ridge } \\
\text { count }\end{array}$ & $\begin{array}{l}L^{u} \\
13\end{array}$ & $\begin{array}{c}\mathrm{L}^{\mathrm{u}} \\
6\end{array}$ & $\begin{array}{l}\mathrm{L}^{\mathrm{u}} \\
8 \\
8\end{array}$ & $\mathbf{L}^{\mathrm{u}}$ & $\begin{array}{l}L^{\prime \prime} \\
14\end{array}$ & 51 & $L / D$ & O & $\mathbf{L}$ & + & $36^{\circ}$ & $A^{u}$ & O & $\mathbf{t}^{\prime}$ \\
\hline Right & $\begin{array}{l}\text { Pattern } \\
\begin{array}{c}\text { Ridge } \\
\text { count }\end{array}\end{array}$ & $\begin{array}{l}L^{u} \\
13\end{array}$ & $\mathrm{~L}^{\mathrm{u}}$ & $\mathbf{L}^{\mathbf{u}}$ & $\mathrm{L}^{\mathrm{u}}$ & $\mathrm{L}^{\mathrm{u}}$ & 66 & 0 & O & O & + & $40^{\circ}$ & $\mathbf{A}^{\mathbf{u}}$ & O & $\mathbf{t}^{\prime}$ \\
\hline
\end{tabular}

pulse was normal to palpation. The venous pressure was not raised, and venous pulse had normal a, c, and $v$ components. The apical impulse was normal, and there was no clinical evidence of cardiac enlargement. A grade $2 / 6$ systolic ejection murmur was maximal in the second and third intercostal spaces in the parasternal line. There were no diastolic murmurs or third or fourth heart sounds. Slight peripheral cyanosis was present in the nail beds.

Laboratory studies showed a white blood cell count of 6900 , with $73 \%$ polymorphonuclear leucocytes, $1 \%$ basophils, $14 \%$ lymphocytes, $5.5 \%$ atypical lymphocytes, and $6 \%$ monocytes. Slight hypersegmentation of the neutrophils was noted, $14,38,35,10$, and $3 \%$ having $2,3,4,5$, and 6 lobes, respectively. Haematocrit was 39 , haemoglobin $12.7 \mathrm{~g} . / 100 \mathrm{ml}$., and red cell count $4.71 \times 10^{6} / \mathrm{cu}$. mm. There were $1.9 \%$ reticulocytes, and platelets numbered 399,000/cu. mm. The serum iron was $44 \mu \mathrm{g}$. $/ 100 \mathrm{ml}$., with a total iron-binding capacity of $360 \mu \mathrm{g} . / 100 \mathrm{ml}$. and a saturation of $12 \%$. The urinalysis was normal. 24-hour urine collections were hampered by incontinence and recurrent watery diarrhoea. The 17-hydroxysteroids ranged from $1 \cdot 1$ mg. to $1.9 \mathrm{mg}$. daily, and the 17 -ketosteroids from 1.3 mg. to $4.2 \mathrm{mg}$., rising to $4.5 \mathrm{mg}$. and $5.0 \mathrm{mg}$., respectively, after metyrapone. Tests for urinary follicle stimulating hormone activity were negative at 10 and 60 mouse units. The stools were watery and showed occasional muscle fibres, but were guaiac negative. A 72-hour stool collection for fat revealed an excretion of $8.2 \mathrm{~g}$. daily. The serum carotene was $184 \mu \mathrm{g} . / 100 \mathrm{ml}$., and the serum vitamin A $16 \mathrm{mg} . / 100 \mathrm{ml}$. The prothrombin time was $81 \%$, and the fasting blood sugar was $70 \mathrm{mg} . / 100 \mathrm{ml}$. Oral glucose and lactose tolerance tests were normal. Other laboratory studies included blood urea nitrogen, $12 \mathrm{mg} . / 100 \mathrm{ml}$; uric acid, $5.9 \mathrm{mg} . / 100 \mathrm{ml}$; serum sodium, $135 \mathrm{mEq} / 1$. ; potassium, $3.6 \mathrm{mEq} / 1$; chloride, $106 \mathrm{mEq} / \mathrm{l}$.; bicarbonate, $22 \mathrm{mEq} / \mathrm{l}$.; and total protein, $7.6 \mathrm{~g} . / 100 \mathrm{ml}$., with $5.2 \mathrm{~g} . / 100 \mathrm{ml}$. albumin and $2.4 \mathrm{~g}$. globulin.

The results of blood typing of the patient and her parents are shown in Table I and the dermatoglyphic findings are summarized in Table II. Immunoglobulin levels in the patient, her parents, and, for comparison, a family with a partial E-18 long arm deletion are given in Table III.

TABLE III

RESULTS OF SERUM IMMUNOGLOBULIN ASSAYS

\begin{tabular}{c|c|c|c}
\hline & \multicolumn{3}{|c}{ Immunoglobulin Fraction } \\
\cline { 2 - 4 } Subject & $\begin{array}{c}\text { IgA } \\
\text { (mg./100 ml.) }\end{array}$ & $\begin{array}{r}\text { IgM } \\
(\mathrm{mg} / 100 \mathrm{ml} .)\end{array}$ & $\begin{array}{c}\text { IgG } \\
\text { (mg./100 ml. })\end{array}$ \\
\hline Patient, E-18 ring & 210 & 89 & 1250 \\
Father & 90 & 89 & 560 \\
Mother & 185 & 89 & 500 \\
4-mth.-old & & & \\
female with & & & 220 \\
E-18 long arm & 25 & 195 & 1250 \\
deletion & 265 & 150 & 1300 \\
Father & 90 & & \\
Mother* & & & \\
\hline
\end{tabular}

$\star$ Balanced translocation carrier.

TABLE IV

DISTRIBUTION OF CHROMOSOME COUNTS IN 212 CELLS

\begin{tabular}{l|c|c|c|c|c}
\hline \multirow{2}{*}{ Tissue } & \multicolumn{2}{|c|}{ Chromosome No. } & Total \\
\cline { 2 - 5 } & $<44$ & 44 & 45 & 46 & \\
\hline Blood & 3 & 3 & 13 & 81 & 100 \\
Marrow & 8 & 9 & 15 & 80 & 112 \\
\hline
\end{tabular}




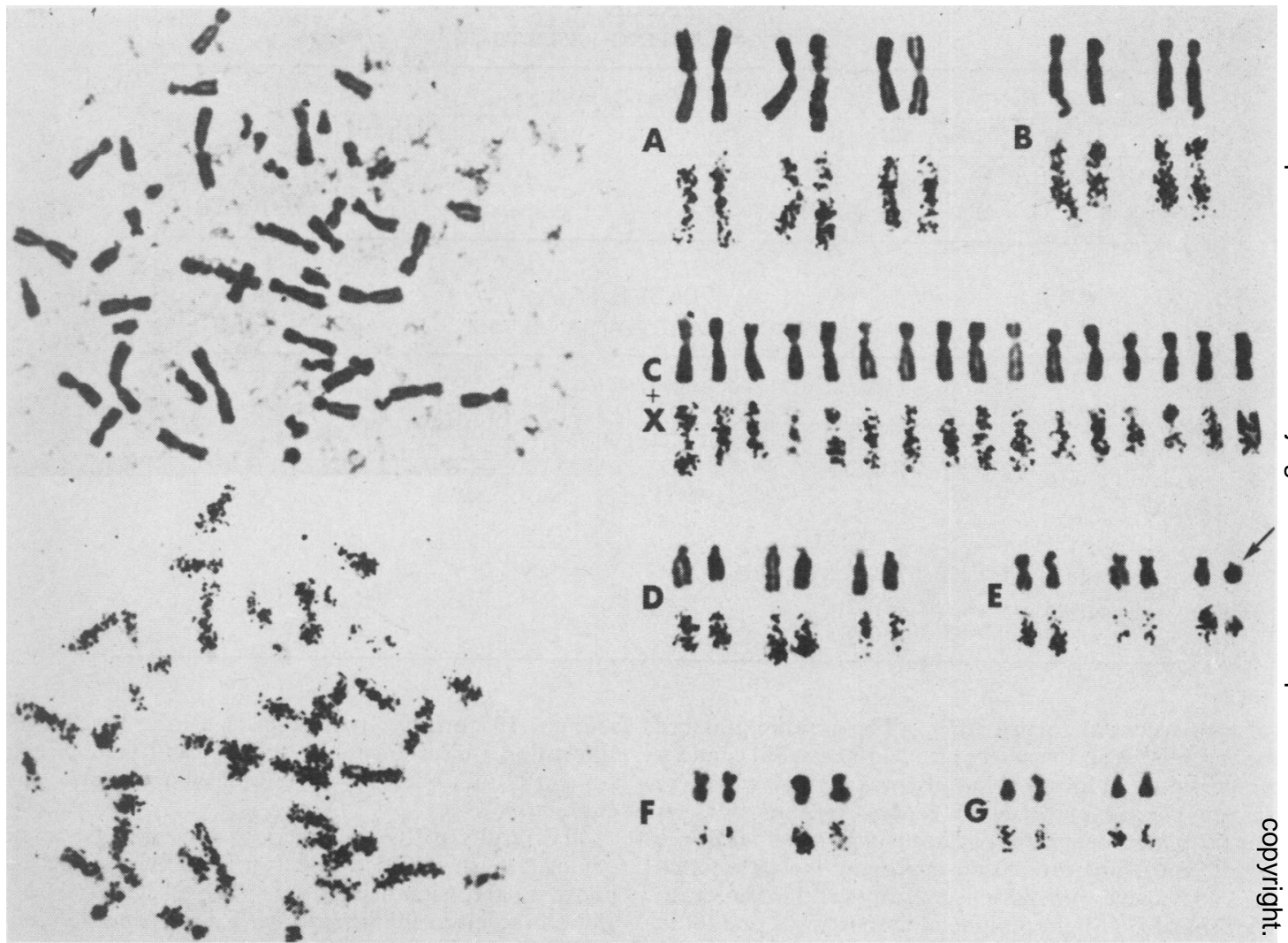

FIG. 2. Metaphase preparation of a peripheral blood cell showing chromosomal morphology and tritiated thymidine labelling pattern. Two members of the E 17-18 pairs are early replicators and show little grain (pair 17), while the other two, including the ring chromosome (arrow), are densely labelled, indicating late replication (pair 18).

The results of cytogenetic studies are shown in Table IV and Fig. 2. In both lymphocyte cultures and a direct marrow preparation, cells with 46 chromosomes all showed a ring replacing one of the four members of the 17-18 pairs. In the cells with 45 chromosomes, elimination of the ring, resulting in complete monosomy, was found in 7 of the 9 peripheral leucocytes and 4 of the 13 marrow cells which were karyotyped.

Autoradiographic studies were performed with tritiated thymidine to identify the ring chromosome. For analysis, 18 cells with 46 chromosomes were selected in which the ring could be easily identified, and a relatively late labelling pattern was evident from gross inspection of the metaphase spread. The members of the 17-18 pairs were classified according to their labelling pattern (Table V). Fig. 2 shows a cell in which two members were classified as showing a heavy labelling pattern and two a light labelling pattern. Under the null hypothesis that the 4 chromosomes replicate independently, the expected distribution of labelling patterns among the 18 cells can be determined from expansion of the trinominal $(h+l+u)^{4}$, where $h, l$, and $u$ are the observed frequencies of heavily labelled, lightly labelled, and unlabelled 17-18 members, respectively. It can be seen
TABLE V

AUTORADIOGRAPHIC LABELLING PATTERN OF E 17-18 CHROMOSOMES

\begin{tabular}{|c|c|c|c|c|c|}
\hline \multirow{2}{*}{ Class } & \multicolumn{2}{|c|}{ No. of Cells } & \multicolumn{3}{|c|}{$\begin{array}{l}\text { Labelling Pattern: No. of } \\
\text { Chromosomes }\end{array}$} \\
\hline & Observed & Expected & $\begin{array}{l}\text { Heavily } \\
\text { Labelled }\end{array}$ & $\begin{array}{l}\text { Lightly } \\
\text { Labelled }\end{array}$ & Unlabelled \\
\hline $\begin{array}{l}1 \\
2 \\
3 \\
4 \\
5 \\
6 \\
7\end{array}$ & $\begin{array}{l}6 \\
7 \\
1 \\
1 \\
1 \\
1 \\
1\end{array}$ & $\begin{array}{l}1.65 \\
1.65 \\
0.64 \\
2.06 \\
0.70 \\
0.68 \\
3.29\end{array}$ & $\begin{array}{l}2 \\
2 \\
0 \\
1 \\
4 \\
1 \\
2\end{array}$ & $\begin{array}{l}0 \\
2 \\
2 \\
1 \\
0 \\
0 \\
1\end{array}$ & $\begin{array}{l}2 \\
0 \\
2 \\
2 \\
0 \\
3 \\
1\end{array}$ \\
\hline $8-15$ & 0 & $7 \cdot 33$ & \multicolumn{3}{|c|}{ All other combinations } \\
\hline
\end{tabular}

in Table $\mathrm{V}$ that the null hypothesis is rejected: there is an excess of cells in the classes (1-3) that show two chromosomes with each of two labelling patterns, a distribution that suggests a differential labelling pattern for $\mathscr{\Phi}$ homologous chromosome pairs. Because the ring? chromosome was heavily labelled in all but one cell (where it was lightly labelled), it is inferred to be a 
member of pair 18. It is possible that the anomaly itself delays replication of the ring. But even if this were true and the ring were a member of the early replicating pair, identification would still be possible because a different distribution of labelling patterns would be expected, with more cells showing three labelled chromosomes. In summary, the patient is a $45, \mathrm{XX} \mathrm{E}-/ 46$, $\mathrm{XX}$, Er mosaic, and the ring chromosome is probably a member of pair 18 .

An electrocardiogram showed left axis deviation without conduction abnormality or ventricular dominance. Chest $x$-rays (Fig. 3A) showed bilateral cervical ribs and apparent biventricular enlargement without widening of the superior mediastinum. Right heart catheterization was performed through a right saphenous vein. Pressures and oxygen saturations were normal in all chambers. Persistence of the left superior vena cava draining into the left atrium was demonstrated by passage of a catheter from the left median basilic vein. Left atrial oxygen saturation was $78 \%$, and the femoral artery saturation was $82 \%$. The left atrial pressure tracing showed an 'a' wave of $16 \mathrm{~mm}$. $\mathrm{Hg}$ and a ' $v$ ' wave of $12 \mathrm{~mm}$. $\mathrm{Hg}$. The left ventricular pressure was 135 $\mathrm{mm}$. $\mathrm{Hg}$ systolic and 0 to $15 \mathrm{~mm}$. $\mathrm{Hg}$ diastolic, with a simultaneous femoral artery pressure of $100 / 60 \mathrm{~mm} . \mathrm{Hg}$. The peak-to-peak systolic gradient across the left ventricular outflow tract was $35 \mathrm{~mm}$. $\mathrm{Hg}$. The left ventricular and arterial pulse tracings had normal contours. Dye dilution curves excluded the presence of any intracardiac shunt. Cine-angiocardiograms confirmed the presence of a left superior vena cava draining directly into the left atrium (Fig. 3B). The mitral valve appeared normal, but as contrast material passed into the left ventricular outflow tract, obstruction secondary to a hypertrophied left ventricular septum was noted (Fig. $3 \mathrm{C}$ and $\mathrm{D})$. There was no abnormality of the aortic valve or aorta, nor was there a septal defect.

Temporal bone tomography showed hypoplasia of the middle ear.

\section{Comment}

Persistence of a left superior vena cava has become recognized as a relatively common disorder since the introduction of cardiac catheterization and angiography (Fraser et al., 1961). A persistent

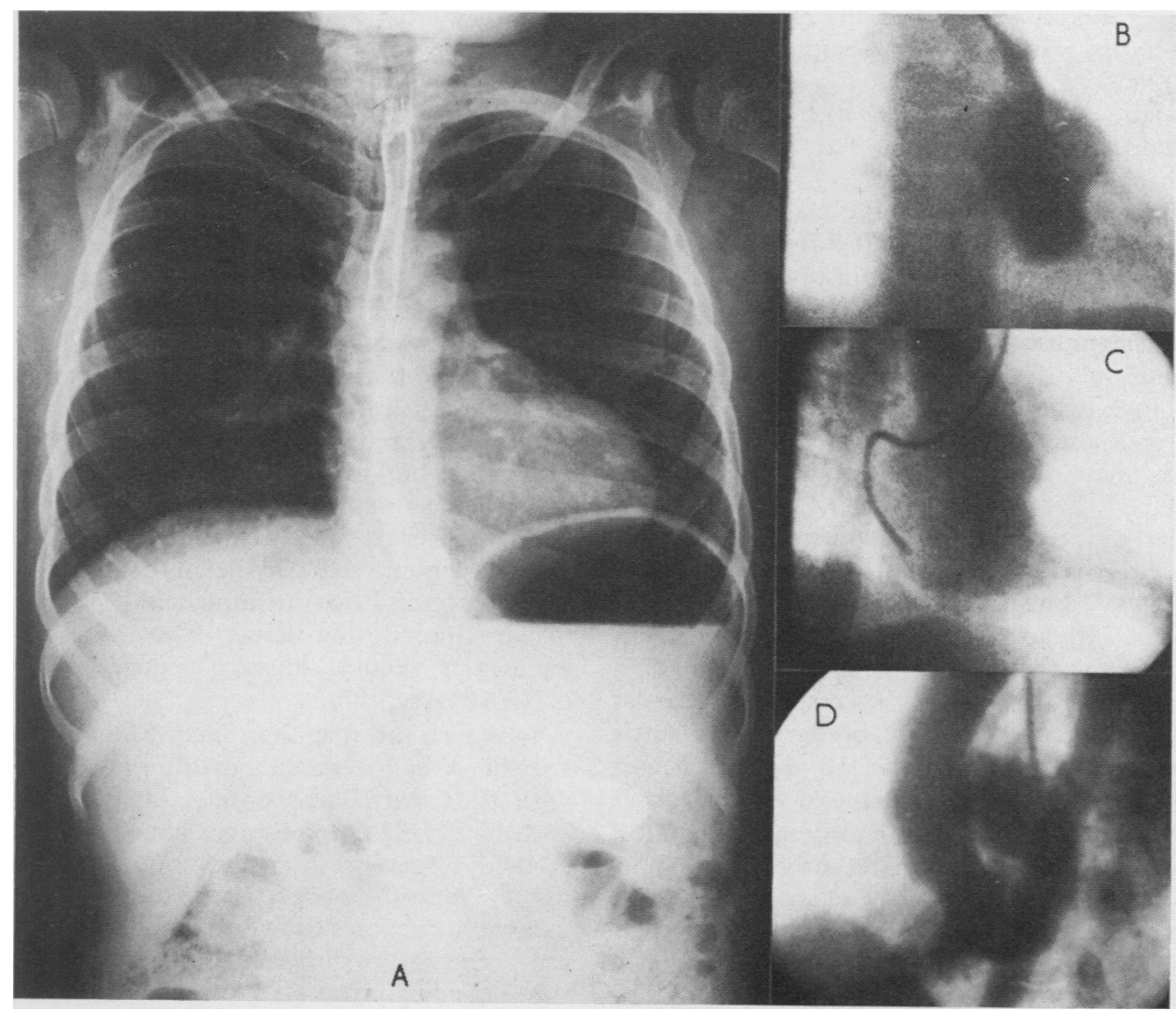

Fig. 3. Chest film and single frames from cine-angiocardiography. (A) Cardiac enlargement without widening of the superior mediastinum. (B) Left superior vena cava draining into the left atrium. (C and D) Left ventricular outflow tract obstruction from the right
and left anterior oblique positions. 
left superior vena cava is often accompanied by other cardiac anomalies, but there is no previous report of association with hypertrophic subaortic stenosis. Tuchman et al. (1956) have described a patient with moderate left ventricular hypertrophy and a left superior vena cava draining into the left atrium, but the haemodynamic burden associated with the right-to-left shunt may well have been the cause of the left ventricular hypertrophy in their case. The increased flow across the mitral valve may be associated with a diastolic flow murmur (Davis, Jordaan, and Snyman, 1959), though none was heard in our patient.

Hypertrophic subaortic stenosis has been reported to occur with atrioventricular canal defects (Molthan et al., 1962), coarctation of the aorta (McIntosh et al., 1962), ventricular septal defect (Lauer et al., 1960), and persistent ductus arteriosus (Goodwin et al., 1961). Finally, Shone and his colleagues (1963) have described a complex developmental malformation in 8 patients, consisting of 'parachute mitral valve', supravalvular ring of the left atrium, coarctation of the aorta, and subaortic stenosis. In 5 of the 8 patients, left ventricular obstruction was caused by a hypertrophied ventricular septum, but in no case was there an associated persistence of the left superior vena cava.

Our patient did not have the classical physical findings of hypertrophic subaortic stenosis, such as a bisferiens type pulse with rapid upstroke, double apical impulse, or atrial sound (Braunwald et al., 1964). Her murmur was considered functional by many, and only the presence of cyanosis prompted further investigation. Clearly, hypertrophic subaortic stenosis can exist in such a mild form that the diagnosis may not be suggested by the physical findings.

Similarly, since persistent left superior venae cavae usually drain into the right atrium (Meadows and Sharp, 1965), one would not expect cyanosis in most cases. Radiographic findings, such as a vascular pedicle, a thoracic ratio greater than $27 \%$ (Gensini et al., 1959), or a crescentic vascular shadow passing from the left border of the aortic arch toward the middle of the left clavicle (Fraser et al., 1961), may be the only clue to this diagnosis.

The clinical findings in 10 reported cases of $\mathrm{E}$ ring chromosome have been recently reviewed by de Grouchy, Herrault, and Cohen-Solal (1968). To some extent, the features observed are a composite of the abnormalities seen in patients with isolated E-18 short arm deletion and in the E-18 long arm deletion syndrome (Nance and Engel, 1967a), a possible consequence of the loss of chromosomal material from both arms during formation of the ring. Since the review of de Grouchy and col- $\mathbb{\Phi}$ leagues, two additional cases have been reported by $\underset{\oplus}{\stackrel{\Phi}{+}}$ Aula et al. (1967) and a third by Scott (1968). Only in the cases of Gropp, Jussen, and Ofteringer (1964) and of Palmer, Fareed, and Merritt (1967) is mention $\frac{}{2}$ made of an associated cardiac defect. In the former 흘 case, a 'systolic-diastolic murmur' was interpreted as $\frac{\bar{m}}{\overrightarrow{7}}$ suggesting a ventricular septal defect. In the $\stackrel{\mathbb{Q}}{\varrho}$ latter case, heart murmur, cyanosis, and cardiomegaly were present, and cardiac catheterization, $\vec{D}$ including cine-angiography, revealed a moderate left-to-right atrial shunt, a small left ventricle with $\vec{\omega}$ an intact septum, and total pulmonary venous drainage into the right ventricle, probably via the coronary sinus.

Atrial septal defect and anomalous pulmonary venous drainage are the two congenital heart defects that are most commonly found in association with persistence of the left superior vena cava (Gensini et al., 1959). It seems likely that a common pathogenic mechanism-namely, a delay or total failure of left superior vena caval regression-may be the explanation for this association. The pulmonary veins normally arise from out-pocketings of the $\stackrel{\mathbb{D}}{\square}$ presumptive left atrial wall (Neill, 1956) under the $\vec{\bullet}$ inductive influence of the adjacent lung primordiuns 8 In contrast to the rather fixed and stereotype differentiation of the phylogenetically olde⿳亠丷厂 Cuvierian system, pulmonary vein induction is $\vec{a}^{+}$ labile process: virtually any suitably located vein may be induced to give rise, on occasion, to anomalous pulmonary venous drainage to the superior venae cavae, the innominate vein, the azygos vein, the coronary sinus, or even the portal vein. If the left superior vena cava remains patent throughout embryonic life or even if its closure is only briefly delayed, this vein itself or the coronary sinus to which it gives rise can become the site of pulmonary vein induction, since they lie on the posteriocephalic surface of the heart in immediate juxtaposition to the developing lung tissue. Once established, the anomalous venous drainage supports the patency of the atrial septum.

It is possible that there may be some degree of specificity in the cardiac malformations associated with E-18 partial monosomy. Only two patients with E-18 ring chromosomes have been adequately studied to reveal anomalous pulmonary and systemic venous drainage to the heart, and in both cases abnormalities were found. Since these lesions may often be asymptomatic, they may have been overlooked in other cases of E-18 partial monosomy, and routine angiographic studies should, therefore, be considered in this group of patients. 
Atrial septal defect has also been reported in a patient with an E-18 short arm deletion (Nitowsky et al., 1966), and cardiac abnormalities were noted in 8 of 19 cases of E-18 long arm deletion reviewed by de Grouchy (1969). Congenital heart disease is also a recognized component of the E-18 trisomy syndrome, the most commonly observed malformations being ventricular septal defect and patent ductus arteriosus (Warkany, Passarge, and Smith, 1966).

Chromosome deletions provide an unusual opportunity for the localization of specific autosomal genes in man (Nance and Engel, 1967b). Our patient was shown to be heterozygous at the $M N$ and Kidd loci; hence these genes cannot have been included in the deleted segment. In other subjects with E-18 ring chromosomes, blood typing has, in addition, permitted exclusion of the Duffy, haptoglobin, alkaline phosphatase, $\mathrm{Gm}$, and red cell acid phosphatase loci (de Grouchy et al., 1964, 1968; Palmer et al., 1967; Petit and Poncelet, 1967). Feingold and colleagues (1968) have reported IgA deficiency in patients with E-18 partial monosomy, and suggested that a locus concerned with immunoglobulin production may be located on chromosome 18. The immunoglobulin levels in the present case were all normal. In a previously reported 4-month-old girl with familial E-18 partial long arm deletion (Nance et al., 1968), all three immunoglobulin fractions studied were present but reduced in amount (Table III).

\section{Summary}

The coincidence of persistence of the left superior vena cava and subaortic stenosis has been documented in a 12-year-old girl with an E-18 ring chromosome. Cardiac anomalies resulting from delay or failure of involution of the left superior vena cava may be specifically associated with E-18 partial monosomy. The lesions may be clinically inapparent and require angiography for their demonstration.

We gratefully acknowledge the assistance of Dr. Bruce Chown, Winnipeg, Canada, in performing the blood group determinations.

\section{REFERENCES}

Aula, P., Gripenberg, U., Hjelt, L., Kivalo, E., Leisti, J., Palo, J., von Schoultz, B., and Suomalainen, E. (1967). Two cases with a ring chromosome in group E. Acta neurol. scand., 43, 31, Suppl., 51.

Braunwald, E., Lambrew, C. T., Rockoff, S. D., Ross, J. Jr., and Morrow, A. G. (1964). Idiopathic hypertrophic subaortic stenosis. I. A description of the disease based upon an analysis of 64 patients. Circulation, 30, Suppl. IV, 3.
Davis, W. H., Jordaan, F. R., and Snyman, H. W. (1959). Persistent left superior vena cava draining into the left atrium, as an isolated anomaly. Amer. Heart f., 57, 616.

Feingold, M., Schwartz, R. S., Atkins, L., Anderson, R., Bartsocas, C. S., Page, D. L., and Littlefield, J. W. (1968). IgA deficiency associated with partial deletion of chromosome 18. Clin. Res., 16, 200.

Fraser, R. S., Dvorkin, J., Rossall, R. E., and Eidem, R. (1961). Left superior vena cava. A review of associated congenital heart lesions, catheterization data and roentgenologic findings. Amer. f. Med., 31, 711.

Gensini, G. C., Caldini, P., Casaccio, F., and Blount, S. G., Jr. (1959). Persistent left superior vena cava. Amer. F. Cardiol., 4, 677.

Goodwin, J. F., Gordon, H., Hollman, A., and Bishop, M. B. (1961). Clinical aspects of cardiomyopathy. Brit. med. $\mathcal{F} ., 1,69$.

Gropp, A., Jussen, A., and Ofteringer, K. (1964). Multiple congenital anomalies associated with a partially ring-shaped chromosome probably derived from chromosome no. 18 in man. Nature (Lond.), 202, 829.

Grouchy, J. de (1969). Chromosome 18 deletions. In The First Conference on the Clinical Delineation of Birth Defects. Ed. by Daniel Bergsma. Birth Defects Original Article Series, Volume 5. National Foundation-March of Dimes, New York. In the press.

- , Herrault, A., and Cohen-Solal, J. (1968). Une observation de chromosome 18 en anneau (18r). Ann. Génét., 11, 33.

, Leveque, B., Debauchez, C., Salmon, C., and Marie, J. (1964). Chromosome 17-18 en anneau et malformations congénitales chez une fille. ibid., $7,17$.

Lauer, R. M., DuShane, J. W., and Edwards, J. E. (1960). Obstruction of left ventricular outlet in association with ventricular septal defect. Circulation, 22, 110.

McIntosh, H. D., Sealy, W. C., Whalen, R. E., Cohen, A. I., and Sumner, R. G. (1962). Obstruction to outflow tract of left ventricle. Arch. intern. Med., 110, 312.

Meadows, W. R., and Sharp, J. T. (1965). Persistent left superior vena cava draining into the left atrium without arterial oxygen unsaturation. Amer. F. Cardiol., 16, 273.

Molthan, M. E., Paul, M. H., and Lev, M. (1962). Common A-V orifice with pulmonary valvular and hypertrophic subaortic stenosis. ibid., 10, 291.

Nance, W. E., and Engel, E. (1967a). Human cytogenetics: A brief review and presentation of new findings. $\mathcal{F}$. Bone $f t$ Surg., 49-A, 1436.

, and - (1967b). Autosomal deletion mapping in man. Science, 155, 692.

-, Higdon, S. H., Chown, B., and Engel, E. (1968). Partial E-18 long-arm deletion. Lancet, 1, 303.

Neill, C. A. (1956). Development of the pulmonary veins with reference to the embryology of anomalies of pulmonary venous return. Pediatrics, 18, 880.

Nitowsky, H. M., Sindhvananda, N., Konigsberg, U. R., and Weinberg, T. (1966). Partial 18 monosomy in the cyclops malformation. ibid., 37, 260.

Palmer, C. G., Fareed, N., and Merritt, A. D. (1967). Ring chromosome 18 in a patient with multiple anomalies. f. med. Genet., 4, 117.

Petit, P., and Poncelet, R. (1967). Un nouveau cas de chromosome 18 en anneau (18r). Ann. Génét., 10, 134.

Scott, C. I. (1968). Ring chromosome 17-18. In The Clinical Delineation of Birth Defects, Baltimore, May 20-25, p. 185.

Shone, J. D., Sellers, R. D., Anderson, R. C., Adams, P., Jr., Lillehei, C. W., and Edwards, J. E. (1963). The developmental complex of 'parachute mitral valve,' supravalvular ring of left atrium, subaortic stenosis and coarctation of aorta. Amer. F. Cardiol., 11, 714.

Tuchman, H., Brown, J. F., Huston, J. H., Weinstein, A. B., Rowe, G. G., and Crumpton, C. W. (1956). Superior vena cava draining into left atrium. Another cause for left ventricular hypertrophy with cyanotic congenital heart disease. Amer. F. Med., 21, 481

Warkany, J., Passarge, E., and Smith, L. B. (1966). Congenital malformations in autosomal trisomy syndromes. Amer. $\mathscr{f}$. Dis. Child., 112, 502. 